\title{
High cognitive demand tasks may detect mild alterations in executive functions in American football players: A pilot study
}

\author{
Paul Carrillo-Mora ${ }^{1 *}$, Vania Aldrete-Cortez ${ }^{2}$, Jorge A. Guzmán-Cortés ${ }^{3}$, Guadalupe García-de la Torre ${ }^{4}$ \\ Laura Tirado-Gómez ${ }^{4}$, Luz Navarro ${ }^{4}$, María Soto-Lara ${ }^{4}$, Kenia F. Franyutti-Prado ${ }^{5}$, and \\ Karina G. Barajas-Martínez ${ }^{6}$
}

${ }^{1}$ Neuroscience Division, Instituto Nacional de Rehabilitación LGII, Mexico City; ${ }^{2}$ Laboratory of Neuroscience and Cognitive Development, School of Psychology, Universidad Panamericana, Mexico City; ${ }^{3}$ Escuela Superior de Actopan, Universidad Autónoma del Estado de Hidalgo, Hidalgo; ${ }^{4}$ Faculty of Medicine, Universidad Nacional Autónoma de México, Mexico City; ${ }^{5}$ Hospital General "Dr. Fernando Quiroz Gutiérrez,"Internal Medicine Service, Instituto de Seguridad y Servicios Sociales de los Trabajadores del Estado (ISSSTE), Mexico City; ${ }^{6}$ Departamento de Consulta de Especialidad, Hospital Fundación Nuestra Señora de la Luz, Mexico City. Mexico

\begin{abstract}
Background: Repeated head trauma associated with sports activities can cause subtle cognitive alterations in amateur players, but these are difficult to detect. Objective: The objective of this pilot study was to determine if there is an association between executive functions performance and different sports practice variables in a sample of amateur American football players. Methods: A pilot transversal study with amateur American football male players without previous neurological or psychiatric illnesses, drug abuse, or consumption of psychotropic medications were carried out and evaluated executive functions performance using automated test. In addition, the levels of stress, impulsivity, and symptoms of anxiety and depression were evaluated, as well as multiple variables related to sports practice such as previous concussions, time of sports practice, weekly training time, and position within the game. Results: Fourteen men players were assessed, with an average age of 20.57 (standard deviation $[S D] \pm 1.61$ ) years, played $7(50 \%)$ in an offensive position, $7(50 \%)$ in defensive position, and $3(21 \%)$ presented previous sport-related brain trauma. The average time of practice football was of 35.07 (SD \pm 43.10$)$ months, starting age of football playing 17.71 (SD \pm 3.64 ), and hours of training during the week $5.75(S D \pm 2.83)$. There was no association between cognitive performance and any sports practice variable, however, the offensive position showed significant association with impairments in the highest span of visual working memory task $(\beta=0.53, S E=0.16, p=0.001$ ). Conclusion: The results suggest that executive tasks with high cognitive demand may reveal alterations in the short term in amateur American football players.
\end{abstract}

Key words: Traumatic brain injury. Concussion. Executive functions. Sports. Cognition.

\section{Tareas de alta demanda cognitiva pueden detectar alteraciones leves en funciones ejecutivas en jugadores de futbol americano. Estudio piloto}

\section{Resumen}

Antecedentes: El trauma craneal repetido asociado a actividades deportivas puede provocar alteraciones cognitivas sutiles en jugadores amateurs, pero estas son difíciles de detectar. Objetivo: El objetivo de este estudio piloto fue determinar si existe asociación entre el rendimiento en las funciones ejecutivas con distintas variables de práctica deportiva en jugadores

Date of reception: 24-04-2021

*Paul Carrillo-Mora

E-mail: neuropolaco@yahoo.com.mx

Available online: 15-11-2021 Rev Mex Neuroci. 2021;22(5):219-223 www.revmexneurociencia.com 2604-6180/ @ 2021 Academia Mexicana de Neurología A.C. Published by Permanyer. This is an open access article under the CC BY-NC-ND license (http://creativecommons.org/licenses/by-nc-nd/4.0/).
} 
de futbol americano amateur. Material y métodos: Se realizó un estudio piloto transversal en jugadores de fútbol americano amateur sin antecedentes de enfermedades neurológicas, psiquiátricas, abuso de drogas o consumo de psicofármacos, y se evaluó el desempeño de las funciones ejecutivas mediante una prueba computarizada. Además, se evaluaron los niveles de estrés, impulsividad y síntomas de ansiedad y depresión, así como múltiples variables relacionadas con la práctica deportiva. Resultados: Se evaluaron 14 jugadores del sexo masculino, con una edad promedio de 20.57 años (DE \pm 1.61 ), $7(50 \%)$ jugaban en posición ofensiva y $7(50 \%)$ en posición defensiva; $3(21 \%)$ presentaron trauma craneal deportivo previo. El tiempo promedio de práctica deportiva fue de 35,07 meses ( $D E \pm 43.10$ ), la edad de inicio fue de 17.71 años (DE \pm $3,64)$ y las horas de entrenamiento semanal de 5.75 ( $D E \pm 2.83$ ). No hubo asociación entre el rendimiento cognitivo con ninguna variable de la práctica deportiva, sin embargo, la posición ofensiva mostró una asociación significativa con las alteraciones en el rango más alto de la tarea de memoria de trabajo visual $(\beta=0.53, S E=0.16, p=0.001$ ). Conclusiones: $L o s$ resultados sugieren que las tareas de funciones ejecutivas con alta demanda cognitiva pueden revelar alteraciones a corto plazo en jugadores de fútbol americano amateurs.

Palabras clave: Daño cerebral traumático. Concusión. Funciones ejecutivas. Deportes. Cognición.

\section{Introduction}

The study of repeated head trauma $(\mathrm{RHT})$ in contact sports has recently become more relevant because association between chronic RHT and long-term development of serious neurodegenerative diseases such as chronic traumatic encephalopathy (CTE), but also due to recent studies, suggests an increase in the incidence of concussion related to sports activities in the past decades, particularly in young women ${ }^{1-3}$. This global concern has led to the recent publication of several guidelines for the diagnosis and management of concussion associated with sports activities ${ }^{4,5}$, as well as an effort to develop and validate the use of serum, cerebrospinal fluid, and neuroimaging biomarkers to support the diagnosis of CTE in vivo ${ }^{6,7}$.

The development of cognitive and behavioral disturbances in RHT related to contact sports seems to require a significant exposure time, such as CTE, whose presentation latency ranges from a few years to several decades after stopping the sports activity ${ }^{8}$. In this sense, various studies have shown that the number of years of sports practice as well as the age of onset in sport activity have an influence on the cognitive alterations that are present in sport-related brain trauma ${ }^{9,10}$. Acute alterations (0-24 h) after trauma have been consistently demonstrated in concussive and subconcussive trauma, including cognitive and other post-concussional symptoms (headache, dizziness, sleep disturbances, etc.). Nevertheless, the follow-up reports show a reversal of those alterations in a period of a few days to 1 month ${ }^{11}$. Despite this, some studies reported that subjects with a history of prior trauma display a slower recovery, suggesting a cumulative effect of repeated injuries ${ }^{12}$.

However, most populations of athletes previously studied often have multiple "neuroprotective" factors (youth, regular physical activity, diet, educational level, etc.). The effects of RHT are challenging to detect especially in the short term, because the subjects may compensate cognitive deficits until the damage reaches a "threshold" level ${ }^{13}$. On the other hand, amateur athletes may have different conditions than professional athletes: (a) fewer hours of physical preparation and training (which makes them more prone to suffer injuries) and (b) having a lesser quality of protective equipment or neuroprotective factors (especially in developing countries).

In the study of cognitive alterations in $\mathrm{RHT}$, emphasis has been placed on the processes that have shown sensitivity to indicate alterations in athletes, such is the case of working memory, decision-making, planning, inhibition, and reaction times ${ }^{14,15}$. In this sense, the use of computerized tests represents an advantage in the study of repeated blows to the head, since it allows the randomized presentation of the stimuli to avoid the learning effect of a pencil and paper test and the measurement of times reaction rate as a measure of processing speed ${ }^{16}$.

For all of the above, it is important to study the cognitive effects of RHT on this group of athletes, especially in developing countries, where this type of research is practically non-existent ${ }^{17,18}$. With all these in mind, the objective of the present research was to determine the association between the performance of executive functions with variables related to sports practice in amateur American football players.

\section{Methods}

The present study was adhered to the principles of the Helsinki Declaration revised in 2008 and was approved by the research and ethics committee of the 
School of Medicine at the Universidad Nacional Autónoma de México (UNAM), and all participants signed and received a copy of the informed consent. An observational, cross-sectional pilot study was carried out in 14 amateur American football players belonging to the team from the School of Medicine at UNAM, Mexico City. The inclusion/exclusion criteria were as follows: male sex, being an active and regular player, without: previous neurological or psychiatric illnesses (included non-sport-related brain trauma), drug abuse, or consumption of psychotropic medications; high levels of stress, impulsivity, or important traits of anxiety and depression that may affect cognitive performance were discarded by the assessment of Hamilton, Beck's, SISCO inventory, and Barratt impulsivity scales. All evaluations were applied before the start of the game season and in an examination-free period. Executive functions (visual-spatial and verbal working memory, inhibition, and speed processing) were assessed by automated tests of the PEBL version 2.1 software (http://pebl. sourceforge.net/). The digit span, Flanker test. and Corsi cubes were the selected sub-tests. These tasks require the subject to identify, remember, and effectively manipulate information about numbers, words, and figures quickly and with increasing complexity. These tasks were chosen because the previous studies suggest that they are more sensitive in detecting changes in patients with sport-related concussion ${ }^{16}$; in addition, the use of the PEBL software allowed to quantify very precisely the errors made in the tasks and also the reaction times of participants, which would not be possible using traditional pencil and paper tests ${ }^{16}$; Likewise, different variables related to their sports activity (age of onset, years of sports practice, position in the game, amount of training days, previous sports concussions, etc.) were collected. Statistical analysis: The data analysis was performed with the statistical package SPSS version 23 (IBM Corp., 2014). To assess the association between variables related to sport activity on score and reaction time in every executive task (dependent variable), with a robust estimator of the maximum likelihood. a generalized linear model of main effects was made. For analyses, the decision rule was set to a value $p \leq 0.05$ with two-tailed hypothesis tests.

\section{Results}

In this study, a total of 22 male players were evaluated (the entire team), however, when applying the inclusion and exclusion criteria, eight participants were eliminated (due to personal history or use of
Table 1. Comparison of players global performance in executive functions tasks

\begin{tabular}{|l|c|c|c|c|}
\hline & $\begin{array}{c}\text { Offensive } \\
(\mathbf{n}=\mathbf{7})\end{array}$ & $\begin{array}{c}\text { Defensive } \\
(\mathbf{n}=\mathbf{7})\end{array}$ & Stat. & $\mathbf{p .}$ \\
\hline $\begin{array}{c}\text { Span digit test } \\
\text { Total corrects }\end{array}$ & $7.29 \pm 2.4$ & $7.71 \pm 1.1$ & 20.50 & 0.62 \\
\hline Total time (ms) & $4.08 \pm 0.4$ & $3.79 \pm 0.7$ & 18.01 & 0.45 \\
\hline $\begin{array}{c}\text { Flanker test } \\
\text { Total errors }\end{array}$ & $48.2 \pm 76.3$ & $50.7 \pm 71.4$ & 23.50 & 0.90 \\
\hline $\begin{array}{c}\text { Total time (ms) } \\
\text { Torsi test }\end{array}$ & $514.8 \pm 196$ & $545.6 \pm 174$ & 17.50 & 0.38 \\
\hline $\begin{array}{c}\text { Total corrects } \\
\text { Total time (ms) }\end{array}$ & $9.8 \pm 1.5$ & $10.5 \pm 1.2$ & 18.00 & 0.45 \\
\hline
\end{tabular}

${ }^{*}$ Data reported by mean (standard deviation)) and compared using the MannWhitney U-test. Stat.: statistic.

psychotropic drugs) and a final sample of 14 men players was included, with an average age of 20.57 (standard deviation $[S D] \pm 1.61)$ years, played $7(50 \%)$ in an offensive position, $7(50 \%)$ in defensive position, and $3(21 \%)$ presented previous brain trauma. The average time of practice football was of $35.07(S D \pm 43.10)$ months, starting age of football playing 17.71 (SD \pm 3.64), and hours of training during the week 5.75 (SD \pm 2.83 ). There were no differences between offensive and defensive players in time of practice, $p=0.989$, starting age of football playing, $p=0.773$, and hours of training during the week, $p=0.353$. Furthermore, there were no differences between offensive and defensive players regarding global performance of digit span test, flanker test, and Corsi test (Table 1). Finally, a significant effect of offensive position controlled for previous cranial trauma was found in the Omnibus test $\chi 2$ (2) = $10.81, p=0.004$, but only in the highest span of visual working memory task (Corsi task level 5) (Table 2).

\section{Discussion}

The results of the present pilot study suggest a significant association between player's offensive position (controlled by previous cranial trauma), with a low cognitive performance but only in the highest span of visual memory task. Likewise, the tasks that evaluate visuospatial working memory with higher cognitive demand (greater number of elements) may be more sensitive to detect the early alterations in amateur athletes who receive repetitive cranial trauma and have multiple factors of neuroprotection. 
Table 2. Multivariable association between sport practice variables and highly demand visual-spatial working memory task

\begin{tabular}{|l|c|c|c|c|c|c|}
\hline Parameter & B & $\beta$ & SE $(\beta)$ & CI 95\% ( $\beta)$ & $\chi^{2}$ Wald & $\mathbf{p}$ \\
\hline Intersection & 4913 & 0.030 & 0.1590 & $(-0.28,34)$ & 0.035 & 0.85 \\
\hline Position (offensive) & -771 & 0.536 & 0.1650 & $(0.21,0.85)$ & 10.54 & 0.001 \\
\hline TCE (presence) & 1032 & -0.552 & 0.0876 & $(-0.72,-0.38)$ & 39.79 & 0.0001 \\
\hline (Scale) & 232,992 & 0.402 & 0.1521 & $(0.19,0.84)$ & &
\end{tabular}

B: beta no standardized; $\beta$ : beta standardized; SE: standard error; $\mathrm{Cl}$ : confidence interval.

Our findings are in agreement with that reported by Baugh et al., 2015, who point out that the player's position is a risk factor in athletes exposed to RHT, since according to their location on the playing field, athletes are exposed to a greater or lesser number of head trauma ${ }^{19,20}$.

Another factor observed in this research is the history of previous head trauma, since a player who previously suffered a trauma is more prone and more vulnerable to the effects of a second trauma, and may also have a cumulative effect ${ }^{21}$.

On the other hand, neuropsychological assessment is considered crucial in the assessment of RHT in athletes $^{22}$. The evidence suggests cognitive impairments in specific processes such as working memory, inhibition, cognitive flexibility, planning, and processing speed $^{23}$. This emphasis on the evaluation of executive (frontal) functions is mainly related to the biomechanics of trauma, in which it is proposed that there is greater damage in frontal orbital and dorsolateral regions, as well as in the anterior and basal portion of the temporal lobes $^{24,25}$.

Based on our preliminary results, we suggest that future research emphasizes on the evaluation of the right frontal functions, especially in tasks with high cognitive demand, and in a larger group of amateur football players. On the other hand, regarding amateur sports practice, we can suggest the rotation of offensive and defensive positions to try to reduce the risk of brain damage. The final purpose of this type of studies is to generate alternatives so that players can carry out a safer sports practice.

\section{Conclusion}

In this group of amateur football players, the offensive position controlled by a history of previous head trauma was related to poor performance in visuospatial working memory task with a higher cognitive demand.

\section{Funding}

The authors declare that there was no source of funding for the realization of this investigation because it was conducted by researchers own financing.

\section{Conflicts of interest}

All authors declare that they have no conflicts of interest with this research or with the publication of its results.

\section{Ethical disclosures}

Protection of human and animal subjects. The authors declare that no experiments were performed on humans or animals for this study.

Confidentiality of data. The authors declare that they have followed the protocols of their work center on the publication of patient data.

Right to privacy and informed consent. The authors have obtained the written informed consent of the patients or subjects mentioned in the article. The corresponding author is in possession of this document.

\section{References}

1. Khurana VG, Kaye AH. An overview of concussion in sport. J Clin Neurosci. 2012;19:1-11.

2. Zetterberg H, Winblad B, Bernick C, Yaffe K, Majdan M, Johansson G, et al. Head trauma in sports-clinical characteristics, epidemiology and biomarkers. J Internal Med. 2019;285:624-34.

3. Schallmo MS, Weiner JA, Hsu WK. Sport and sex-specific reporting trends in the epidemiology of concussions sustained by high school athletes. J Bone Joint Surg Am. 2017;99:1314-20.

4. Silverberg ND, laccarino MA, Panenka WJ, Iverson GL, McCulloch KL, Dams-O'Connor, et al. Management of concussion and mild traumatic brain injury: a synthesis of practice guidelines. Arch Phys Med Rehabil. 2020;101:382-93.

5. Giza CC, Kutcher JS, Ashwal S, Barth J, Getchius TS, Gioia GA, et al. Summary of evidence-based guideline update: evaluation and management of concussion in sports: report of the guideline development subcommittee of the American academy of neurology. Neurology. 2013;80:2250-7.

6. Verduyn C, Bjerke M, Duerinck J, Engelborghs S, Peers K, Versijpt J, et al. CSF and blood neurofilament levels in athletes participating in physical contact sports: a systematic review. Neurology. 2021;96:705-15. 
7. Marklund $\mathrm{N}$, Vedung F, Lubberink M, Tegner $\mathrm{Y}$, Johansson J, Blennow $\mathrm{K}$, et al. Tau aggregation and increased neuroinflammation in athletes after sports-related concussions and in traumatic brain injury patients-a PET/ MR study. Neuroimage Clin. 2021;30:102665.

8. Solomon G. Chronic traumatic encephalopathy in sports: a historical and narrative review. Dev Neuropsychol. 2018;43:279-311.

9. Brett BL, Huber DL, Wild A, Nelson LD, McCrea MA. Age of first exposure to American football and behavioral, cognitive, psychological, and physical outcomes in high school and collegiate football players. Sports Health. 2019;11:332-42.

10. Canseco JA, Franks RR, Karamian BA, Divi SN, Reyes AA, Mao JZ, et al. Overview of traumatic brain injury in American football athletes. Clin J Sport Med. 2021;Mar 24. doi: 10.1097/JSM.0000000000000918.

11. Kontos AP, Elbin RJ, Sufrinko A, Marchetti G, Holland CL, Collins MW. Recovery following sport-related concussion: integrating pre-and postinjury factors into multidisciplinary care. J Head Trauma Rehabil. 2019;34:394-401.

12. Covassin T, Stearne D, Elbin R. Concussion history and postconcussion neurocognitive performance and symptoms in collegiate athletes. J Athletic Training. 2008;43:119-24.

13. Alosco ML, Kasimis AB, Stamm JM, Chua AS, Baugh CM, Daneshvar DH, et al. Age of first exposure to American football and long-term neuropsychiatric and cognitive outcomes. Transl Psychiatry. 2017;7:e1236.

14. Terpstra AR, Vásquez BP, Colella B, Tartaglia MC, Tator CH, Mikulis D, et al. Comprehensive neuropsychiatric and cognitive characterization of former professional football players: implications for neurorehabilitation. Front Neurol. 2019;10:712.

15. Cunningham J, Broglio SP, O'Grady M, Wilson F. History of sport-related concussion and long-term clinical cognitive health outcomes in retired athletes: a systematic review. J Athletic Train. 2020;55:132-8.

16. Moroni $\mathrm{C}$, Belin C. Contribution of the neuropsychological assessment in concussion. Neurochirurgie. 2021;67(3):244-8.
17. Guzmán-Cortés JA, Villalva Sánchez AF, Bernal Hernández J. La neuropsicología en la contusión y conmoción cerebral en el deporte. Neuropsicol Clin. 2016;1:20-8.

18. Orozco-Calderón G, Ruz-Santos I. Decremento de las funciones ejecutivas en deportistas. Ciencia Futuro. 2019;9:116-33.

19. Baugh CM, Kiernan PT, Kroshus E, Daneshvar DH, Montenigro PH, McKee A, et al. Frequency of head-impact-related outcomes by position in NCAA division I collegiate football players. J Neurotrauma. 2015;32:314-26.

20. Zimmerman KA, Kim J, Karton C, Lochhead L, Sharp DJ, Hoshizaki T, et al. Player position in American football influences the magnitude of mechanical strains produced in the location of chronic traumatic encephalopathy pathology: a computational modelling study. J Biomechan. 2021:118:110256.

21. Register-Mihalik JK, Mihalik JP, Guskiewicz KM. Association between previous concussion history and symptom endorsement during preseason baseline testing in high school and collegiate athletes. Sports Health. 2009;1:61-5.

22. Iverson GL, Schatz P. Advanced topics in neuropsychological assessment following sport-related concussion. Brain Injury. 2015;29:263-75.

23. Tapper A, Gonzalez D, Roy E, Niechwiej-Szwedo E. Executive function deficits in team sport athletes with a history of concussion revealed by a visual-auditory dual task paradigm. J Sports Sci. 2017;35:231-40.

24. Patton DA, Mclntosh AS, Kleiven S. The biomechanical determinants of concussion: finite element simulations to investigate tissue-level predictors of injury during sporting impacts to the unprotected head. J Appl Biomechan. 2015;3:264-8.

25. Nolan A, Hennessy E, Krukowski K, Guglielmetti C, Chaumeil MM, Sohal VS, et al. Repeated mild head injury leads to wide-ranging deficits in higher-order cognitive functions associated with the prefrontal cortex. J Neurotrauma. 2018;35:2425-34. 